DOI: https://doi.org//10.32839/2304-5809/2020-83.1-32

UDC 378.016:811.112.2

Fedorenko Yuliia

National University "Yuri Kondratyuk Poltava Polytechnic"

Haiduchenko Tetiana

Centre of Foreign Languages "Status"

\title{
FORMATION OF FUTURE SPECIALISTS' LINGUOCULTURAL COMPETENCE
}

Summary. The article investigates the problem of future specialists' linguocultural competence formation in educational process of higher educational institutions. The requirements of modern life are that the future specialist has to master foreign language as a mean of intercultural communication, which claims the formation of linguocultural competence, which is an integral part of the future specialists' professional communicative competence. Competence is considered as knowledge, abilities and skills in the field of linguistics, pedagogy, theory and practice of learning (language competence, speech competence, socio-cultural and sociolinguistic competences, strategic and discursive competences). Foreign language learning process takes place in the specific conditions of interaction between two languages and cultures, which allows speaking about the phenomena of multilingualism and polyculturism. Students acquire verbal and non-verbal samples of behavior that are widely recognized in other linguistic and cultural communities when using a foreign language, and become aware of national-specific features of native speakers' perception of the world.

Keywords: future specialists' linguocultural competence, professional orientation, polyculturism, linguocultural skills, learning process.

Федоренко Ю.П. Національний університет «Полтавська політехніка імені Юрія Кондратюка»

Гайдученко T.A.

Центр іноземних мов «Статус»

\section{ФОРМУВАННЯ ЛІНГВОКУЛЬТУРНОЇ КОМПЕТЕНТНОСТІ МАЙБУТНІХ ФАХІВЦІВ}

Анотація. У статті досліджено проблему формування лінгвокультурної компетентності майбутніх фрахівців у навчальному процесі вищих навчальних закладів. Зростаючий інтерес до іноземної мови як навчальної дисципліни в сучасному суспільстві, яке прагне до встановлення міжнародних контактів в різних сферах діяльності людини сприяе підвищенню ролі професійної спрямованості в процесі навчання іноземних мов у закладах вищої освіти. Виникає необхідність формувати у навчальному процесі багатомовну особистість, що увібрала в себе цінності своєї рідної та іншомовної культур і яка $є$ готовою до міжкультурної комунікації. На сучасному етапі вирішального значення набуває той фракт, що майбутній фахівець повинен володіти іноземною мовою як засобом міжкультурної комунікації, що передбачае необхідність формування у нього лінгвокраїнознавчої компетенції, що є невід'ємною частиною професійної комунікативної компетенції. Компетентність розглядається як знання, вміння та навички у галузі лінгвістики, педагогіки, теорії та практики навчання (мовна компетентність, мовленнева компетентність, соціокультурна та соціолінгвістична компетентності, стратегічна та дискурсивна компетентності). Процес навчання іноземної мови відбувається в специфічних умовах взаємодії двох мов і культур, що дозволяе говорити про явища багатомовності та полікультурності. Студенти набувають словесних та невербальних зразків поведінки, які широко визнаються в інших мовних та культурних спільнотах при користуванні іноземною мовою, та усвідомлюють національні особливості сприйняття носіями мови світу, що, як правило, призводить до формування міжкультурних комунікативних навичок. У науковому доробку також досліджено структуру знань у навчальному процесі. Визначено набір лінгвокультурних навичок як основи комунікативно-навчальної функції успішного вивчення мови. Виокремлено основні принципи, на яких базується організація процесу навчання у закладах вищої освіти: культурна та спрямованість; професійна спрямованість; комунікативна спрямованість; особистісно-діяльнісна спрямованість; інтенсивна інтелектуалізація навчальної діяльності; інтенсифікація процесу навчання.

Ключові слова: лінгвокультурна компетентність майбутніх фрахівців, професійна спрямованість, полікультурність, лінгвокультурні навички, навчальний процес.

Tntroduction. The growing interest in for1 eign language as a discipline in modern society, that seeks to establish international contacts in various spheres of human activity, contributes to the role of professional orientation in the process of foreign languages teaching in higher educational institutions. There is a need to create a multilingual personality in educational process who has absorbed the values of his native and foreign language cultures and who is ready for intercultural communication. Now the most important is the fact that the future specialist has to mas- ter foreign language as a mean of intercultural communication, which requires the formation of linguacultural competence, which is an integral part of the future specialists' professional communicative competence. We believe that competence is a complex personal formation that consists of knowledge, skills and competences that allow the individual to function effectively in a particular activity. Competence is knowledge, abilities and skills in the field of linguistics, pedagogy, theory and practice of learning (language competence, speech competence, socio-cultural and sociolin- 
guistic competences, strategic and discursive competences) [7]. Human communicative ability is based on the following competencies:

- speech (understanding, speaking, writing);

- language (knowledge of phonetics, graphics, spelling, vocabulary, grammar);

- discursive (communicative skills related to the conditions for the implementation of individual speech functions using appropriate language models);

- sociocultural and sociolinguistic (knowledge, ability to use socio-cultural and sociolinguistic realities in communication and cognition);

- strategic (developing students' ability to learn and improve themselves, the desire to communicate, listen, understand others, adequate assessment, self-esteem).

Sociocultural and sociolinguistic competences are knowledge, the ability to use sociocultural and sociolinguistic realities in communication and cognition. In turn, sociocultural competence can be divided into country studying competence, that is, knowledge of country culture (knowledge of history, geography, economy, government, traditions) and linguocultural competence. Linguocultural competence in the field of language presupposes mastery the peculiarities of speech and non-speech behavior of native speakers in certain communication situations by future specialists. By other words, students have a comprehensive system of ideas about national and cultural features of the country, which allows to associate with the linguistic unit the same information as the native speaker, and thus, to achieve successful communication.

Analysis of recent research and publications. In recent years, the problem of linguistic competence formation has been reflected not only in foreign but also in domestic science. It has been thoroughly investigated in the works of N. Borysko, O. Leontiev, M. Nefedova, R. Minyar-Beloruchev, G. Tomakhin, Y. Passov, E. Turchaninov, M.O. Karpenko, V. Furmanova, N. Tchaikovsky, V.A. Maslova and many other researchers. Scientists M. Nefyodova, T. Lotaryova point to the need to increase the level of linguocultural competence of foreign language teachers. M.O. Karpenko expresses the view that linguocultural and linguistic studies are interacting and there is the groundwork for the study of problem of "language and culture", and has a number of basic theoretical propositions, concepts and terms [5: 89-91]. V.A. Maslova believes that linguistics and linguoculture differ in the fact, that linguistics studies national realities that are reflected in the language [6:12].

Setting of previously unresolved components of a common problem. However, there is still a lack of work in modern science that thoroughly examines the issues of linguocultural competence development and active use of linguocultural studies in foreign language learning. It determines the relevance of our scientific paper.

The aim of our research is to find out the essence of the linguocultural approach, to determine its place, to analyze the possibilities of applying the studied approach in the process of a foreign language learning in institutions of higher education.
The main material. Intercultural communication is based on the idea of interaction and interplay of cultures while preserving the identity of each cultural communicator. In the process of intercultural communication, a new linguistic personality is formed - an active mediator between cultures. In intercultural communication, background knowledge is of great importance. It should be noted that the background knowledge of modern students isn't deep. The main source of information for them today is TV and computer. A paradoxical situation arises: when information sources are available, young people do not know much about things that a cultural person cannot exist without knowing them. Linguistic knowledge is closely related to background knowledge.

When making intercultural contacts, it is important to take into account the level of intercultural competence of the dialogue partner. There are six levels of foreign language mastering: 1) Breakthrough (introductory level). British linguist, D. A. Wilkins called it as "Formal Possession" in his work and John Trim in the same publication as "Introductory". 2) Waystage (medium or "survival"), which reflects the Council of Europe's content specification. 3) Threshold, which also reflects the specific content of the Council of Europe. 4) Vantage (advanced level), which reflects the third content specification of the Council of Europe. This level is defined by D.A. Wilkins as "Limited operational competence" and by J. Trim as "adequate response in current situations". 5) Effective Operational Proficiency, J. Trim called it as "Effective Possession/Competence" and D.A.Wilkins as "Adequate Operational Competence". It represents an advanced level of competence, which is desirable for more complex types of work and study tasks; 6) Mastery (By J. Trim: "Global Possession"; by D.A. Wilkins "Global Operational Competence"). In turn, there are four levels of intercultural competence: "Survival level"; "Level of entry into a foreign language culture", which implies a sufficiently stable and deep knowledge of linguistics; "Appropriation level" when a foreign language representative becomes aware of the culture of different countries; and "Level of the primary and secondary linguistic personality merging." In the course of Linguocultural Studies, the most probable and desirable is the student second level of intercultural competence achievement [8].

Because of the fact, that culture is closely linked to the national mentality, the national identity of its bearer, there is always a matching of national cultures at the conscious and subconscious levels in the act of intercultural communication. At least this statement is valid at the first and second levels of competence.

Nowadays, the most promising approach to linguocountry studying is when mastering a foreign language culture is realized by the means of foreign language and in the process of its studying. In such case, students not only passively learn certain information about the country, but actively participate in the process of learning the realities of the country, developing as subjects of dialogue of cultures. According to such approach, 
students acquire verbal and non-verbal behaviors that are widely recognized in other linguistic and cultural communities when using a foreign language, and become aware of national-specific features of native speakers' perception of the world, which generally leads to the formation of intercultural communicative skills. The first attempt to determine the specific features of the process of integrated study of language and culture in domestic science was made by E.M. Vereshchagin and V.G. Kostomarov, who developed the main background of linguistic and cultural approach to language study [1]. The formation and development of linguistic studies played an important role not only in the methodology of teaching native language to foreigners, but also served as an impetus for the development of foreign language teaching methods in this direction. The linguocultural approach allowed to reflect national culture in linguistic units, to realize methodical purposes and to create new practical materials for foreign language teaching. All of them are aimed at achieving one goal - to prepare future specialists for successful intercultural communication by means of linguistic, socio-cultural, linguocultural and didactic knowledge and skills.

In order to form and improve the linguocultural competence of the foreign language teacher, it is important to study and take into account the peculiarities of national-specific perception of the world, the peculiarities of national characters of native speakers, reflected in their verbal and non-verbal behavior in communication. Ignoring of such knowledge can lead to the failure in successful intercultural communication. Cultural traditions of Ukraine and the UK have much in common, as they are within the framework of European civilization and are linked by political, economic and cultural relations.

Foreign language learning process takes place in the specific conditions of interaction between two languages and cultures, which allows to speak about the phenomena of multilingualism and polyculturism. Multilingualism means "the ability of a person to use two or more languages as a means of communication in most situations, and the ability to use one language and another when necessary"; the ability to "switch" to other behaviors when needed" [3]. Considering that the acquisition of foreign language and culture takes place in the context of multilingualism and polyculturism, it is necessary to expect the interference of different world pictures and the mixing of behavior patterns in situations of intercultural communication. There is a need to predict probable mistakes of linguistic and non-linguistic behavior of students and to develop special techniques that form a mechanism for students to 'switch' from one behavior model to another in the educational process.

The process of linguocultural competence forming includes:

1) formation of students' certain fund of background knowledge that forms the basis of intercultural communication;

2) students' mastering of certain linguocultural minimum, that is, lexical units in which foreign cultural concepts are verbalized;
3) students' mastering of certain verbal and nonverbal behavior samples in situations of intercultural communication [2].

The background knowledge of future specialists' linguistic competence is based on background knowledge. The structure of background knowledge in the educational process consists of: a) information culture (historical, geographical, economic facts, information about social institutions, information about daily life, etc.); b) cultural values (literature, painting, cinema, theater, media, etc.); c) behavioral culture (norms of verbal and non-verbal communication commonly accepted in each linguistic and cultural community).

Professionally oriented formation of linguistic and cultural competence in higher educational institutions means:

1) formation of a complex of linguistic knowledge, abilities and skills in the course of professionally oriented language study as an integral part of communicative competence of a non-authentic linguistic and cultural personality in situations of intercultural communication;

2) formation of vocational linguocultural skills, which provide the teacher with the opportunity to teach foreign language as a mean of intercultural communication.

The basis for the organization of professionally oriented teaching of foreign language in higher educational institutions is the functional structure of pedagogical activity of foreign language teacher. Thus, the communicative-educational function is provided by the following linguocultural skills: 1) to orient students to relation between the language and culture of the country, the peculiarities of national demonstration by means of socio-cultural behavior of its representatives; 2) to orient students to the traits of similarity and difference in the cultures of countries; 3) to create students inner intention to use foreign language as a mean of communication in situations of indirect and direct intercultural communication. It should be realized: a) by using authentic materials (texts, poems, songs, videos, etc.) in the process of foreign language learning; b) by the use of active forms of learning (problem tasks discussions, role-playing games of socio-cultural orientation), which contribute to a more effective assimilation of foreign language culture features; c) by engaging students in various types of extracurricular work (linguocultural studies competitions, meeting with a foreign students, speaking clubs etc.).

Conclusions. Based on the specifics of foreign language learning conditions and tasks of socio-cultural orientation of educational process, we distinguish the basic principles on which the organization of learning process in higher educational institutions is based. They are: 1) cultural and country orientation; 2) professional orientation of educational process; 3) communicative orientation; 4) personal-activity orientation of training, 5) intensive intellectualization of students' educational activity; 6) intensification of learning process.

Therefore, students, future specialists, who study both the language and the culture and linguocultural realities of representatives of a foreign-language society, need to create a unite space where they develop, learn and communicate. 


\section{References:}

1. Vereshchagin Y.M., Kostomarov V.G. (1980). Lingvostranovedcheskaya teoriya slova [Linguocountrystuding Word Theory]. Moskva: Russkiy yazyk, $55 \mathrm{~s}$.

2. Min'yar-Beloruchev R.K. (1999). Kak stat' perevodchikom? [How to become a translator]. Moskva: Gotika, 176 s.

3. Nefedova M.A., Lotareva T.V. (1987). Stranovedcheskiy material i poznavatel'naya aktivnost' uchashchikhsya [Regional material and cognitive activity of students]. IYaSh. № 6. P. 26-28.

4. Tomakhin G.D. (1988). Realii-amerikanizmy [Realities of Americanism]. Posobie po stranovedeniyu. Moskva: Vysshaya shkola, $258 \mathrm{~s}$.

5. Karpenko M.L. (1997). Ponyatie «lingvokul'turologiya», «lingvostranovedenie», «lingvokraevedenie» i ikh sootnoshenie sootnoshenie [The concept of "linguoculturology", "linguistic and regional studies", "linguistic studies" and their ratio]. Yazyk i kul'tura. № 3. P. 89-91.

6. Maslova V.A. (2004). Lingvokul'turologiya [Linguoculturology]: Uchebnoe posobie dlya vysshikh uchebn. zav. Moskva, $208 \mathrm{~s}$.

7. Fedorenko Yu.P. (2005). Formuvannia u starshoklasnykiv komunikatyvnoi kompetentsii v protsesi vyvchennia inozemnoi movy [Formation of students communicative competence in foreign language learning process in high school]: avtoref. dys. ... kand. ped. nauk: spets. 13.00.09 Teoriia navchannia. Volyn. derzh. un-t im. L. Ukrainky. Lutsk, $20 \mathrm{~s}$.

8. Carl Rogers. Alternative Method. URL: http://www2.vobs.at/ludescher/Alternative\%20methods/communicative_ language_teaching.htm

\section{Список літератури:}

1. Верещагин С.М., Костомаров В.Г. Лингвострановедческая теория слова. Москва : Русский язык, 1980. 55 с.

2. Миньяр-Белоручев Р.К. Как стать переводчиком? Москва : Готика, 1999. 176 с.

3. Нефедова М.А., Лотарева Т.В. Страноведческий материал и познавательная активность учащихся. ИЯШ. 1987. № 6. C. 26-28.

4. Томахин Г.Д. Реалии-американизмы. Пособие по страноведению. Москва : Высшая школа, 1988.258 с.

5. Карпенко М.Л. Понятие «лингвокультурология», «лингвострановедение», «лингвокраеведение» и их соотношение соотношение. Язык и культура. 1997. № 3. С. 89-91.

6. Маслова В.А. Лингвокультурология : Учебное пособие для высших учебн. зав. Москва, 2004. 208 с.

7. Федоренко Ю.П. Формування у старшокласників комунікативної компетенції в процесі вивчення іноземної мови : автореф. дис. ... канд. пед. наук : спец. 13.00.09 - Теорія навчання. Волин. держ. ун-т ім. Л. Українки. Луцьк, 2005. 20 с.

8. Carl Rogers. Alternative Method. URL: http://www2.vobs.at/ludescher/Alternative\%20methods/communicative_ language_teaching.htm 